\title{
C.OLLECTION OF DELINQUENT TAXES BY RECOURSE TO THE TAXED PROPERTY
}

\author{
H. K. AlLEN*
}

The procedure for the enforcement of tax liens is only one step-although an important one-in the entire tax collection sequence. All of the various steps are intimately related to one another, and the whole procedure is closely connected with the general fiscal, structural, and administrative aspects of government. Because the tax-sale machinery is so closely related to other devices in the collection procedure, it is difficult to segregate it for special treatment. Moreover, the variations in the laws of the different states governing the enforcement of tax liens are so great as almost to defy comparison. ${ }^{1}$ Finally, the numerous changes which have been made in tax collection laws within the last five years preclude, within the time available, an accurate detailed description of the present status of these laws. ${ }^{2}$

Notwithstanding the wide variation in details, certain general features common to all are discernible in the tax collection laws of the various states. It is-possible, therefore, to describe, illustrate, and appraise these characteristics. For the purpose of this discussion, it is assumed that the collection devices antecedent to the invocation of the tax-sale machinery have been treated elsewhere.

\section{General Nature of Tax Delinquency Laws}

While some consideration has been given in the formulation of tax delinquency laws to the rights of the taxpayer and the attraction of the buyers for the tax liens, the main objective of these laws, if it can properly be said that there has been a well-defined objective, has been to maximize tax collections. Notwithstanding the common objective in tax-delinquency legislation, the wide divergence in the laws in the various states suggests that there is no general agreement as to what constitutes

- Ph.D., I936, University of Illinois. Supervisor of Area Policies and Programs, Land Use Planning Section; Region III, Resettlement Administration, Champaign, Illinois.

'The legal provisions discussed in this article are based on the following sources: Hunter, Legal Provisions Affecting Real Estate Tax Delinquency, Tax Sales, and Redemptions, Bull. No. 48, Bureau of Business Rescarch, Univ. of Illinois (I933); U. S. Bureau of the Census, Current Tax Deringuency by States and Counties-Levies of I932-33 with Corolinary Data (I934); TAx Research Foundation, Tax Systems of the Wordo (6th ed. I935); Alyea, Land Redemption, Studies of Legiszative Probzesas IN Alabama (mimeographed ms., Bureau of Business Research, Univ. of Alabama); Manning, Stafe Tax Legislation (Library of Congress, 1935); St. John, Real Property Tax Collection Procedures (1936) 14 TAx Magazine 326:

'For a survey of these changes, see Smith, Recent Legislative Indulgences to Taxpayers, supra, p. 371. 
a proper procedure. This is not meant to imply that any single procedure would prove equally satisfactory in all states. It does suggest, however, the need for a more careful consideration of the principles which should govern a well-planned tax collection procedure.

The collection of taxes and the sale of property for non-payment of taxes involve fundamental property rights. On the one hand, the institution of private property is sanctioned by constitutional edict; on the other hand, certain powers are reserved over property in the form of taxation, eminent domain, and the police power. The exercise of these powers, in turn, is subject to constitutional limitations. In this manner an equilibrium is established between government and property, and it is the function of the courts to preserve this balance. It is essential, therefore, that any interference with property rights such as are involved in tax delinquency laws should be based on a strictly legal procedure.

\section{- Liabirity for Payment of TAXes}

A common feature of tax-collection laws in every state is that taxes levied upon property are made a lien against the property, and the collection of the taxes is authorized by warrant. Not only is the real property itself liable for taxes levied against it; but in most states personal property may also be distrained and sold for the payment of real estate taxes. ${ }^{3}$ Among the states in which this method of collection is not available are Louisiana, Nebraska, Minnesota, and Washington, and with some exceptions, Arkansas, California and Oregon. Unpaid personal taxes, on the other hand, commonly become a lien upon real estate.

In addition to recourse to the real and personal property of the taxpayer, provision is made for personal liability for the payment of property taxes in the states of Alabama, Georgia, Kentucky, Maryland, Mississippi, New Hampshire, North Carolina, Oklahoma, Tennessee, Virginia and West Virginia. The report of the committee on a model real property tax collection law of the National Municipal League recommends that, "Residents of the state who are owners of real property within the state shall be personally liable for taxes levied against such property, such liability to be enforced by appropriate action as for a debt." 4 This recommendation was limited to residents because it was thought that the imposition of such a liability upon non-resident taxpayers would probably be unconstitutional..$^{5}$

Imprisonment for non-payment of taxes is provided as a further means of stimulating tax payments in Connecticut, Delaware, Maine, Massachusetts, New Hampshire, Pennsylvania, and Vermont. ${ }^{6}$

\footnotetext{
- See Rubin, The Collection of Delinquent Real Property Taxes by Action in Personam, infra, at p. 4x7.

-Report of the Committee on a Model Tax Collection Law of the National Municipal League (1935) 24 NAT. MUN. REv. No. 5 (Supp.) at 297.

For a discussion of this problem, see Rubin, The Collection of Delinquent Real Property Taxes by Action in Personam, infra, at pp. 420-429.

- See id. at p. 418.
} 


\section{Interval Between Delinquency and Sale Date}

Provision is made in every state for delinquent dates, penalties and costs, publication of delinquent lists, and tax sales. The period between the date of delinquency and the time for the sale of property for taxes varies greatly in the different states. While forty states have prescribed rather definitely the length of time that must elapse before property can be sold for taxes, the period is indefinite in Florida, Kentucky, Massachusetts, New Hampshire, New Mexico, Rhode Island, and Vermont.

The length of time between the delinquent date and the sale date for those states which provide for sale to private buyers during the redemption period varies from twenty days in Kentucky to eighteen months in Virginia. This period refers to the first delinquent date if taxes are paid in instalments. A longer period-three years and eight months-is provided in Ohio, but in this state there is no redemption period after the sale.

Under legislation enacted in 1935 , tax sales have been postponed.in seven states, namely, California, Indiana, Maryland, North Carolina, Pennsylvania, Tennessee, and Washington. ${ }^{7}$ Because of pressure from taxpayers sales have been postponed or suspended in some instances by tax officials acting upon their own initiative. The abolition of the fee system in the few cases where it exists will remove an incentive to prolong delinquency.

If no redemption period is allowed after the sale, it is obviously necessary and desirable that the period between the delinquent date and the sale date be sufficiently long to afford the taxpayer a reasonable opportunity to protect his property. In other cases, it is equally desirable that the tax sale should be held at a general sale as soon as practicable after the date of delinquency of the last instalment. It should also be made mandatory that sales be held annually on a definite date. This might no doubt be facilitated by making the collector an appointive rather than an elective office, and requiring him to give a surety bond assuring the faithful performance of his duties, including the strict enforcement of all provisions of the law.

\section{Notice of Sale}

Since the sale of real estate for taxes, as suggested above, involves property rights, due process of law requires adequate notice of the time and place of the contemplated action. Personal notice, either by ordinary or registered mail, is required in some states. The statutes of other states prescribe that notices must be posted on the courthouse door and/or other conspicuous public places. A majority of the states, however, provide that the notice of sale must be published in a newspaper for a certain number of times prior to the sale. The number of insertions required varies from one in Illinois, Missouri, New Mexico, Tennessee, and Washington, to six in New York. Seven states require two consecutive weeks of published notice; eighteen

\footnotetext{
${ }^{\top}$ Manning, supra note $\mathrm{I}$, at 22.
} 
states require three published notices; and thirteen states require four consecutive weekly insertions.

A requirement for the publication of an unreasonable number of notices naturally results in unnecessary costs. It has been reported that costs of advertising delinquent tax lists are unduly high in New York because of the requirement in the statutes for six consecutive weekly insertions. ${ }^{8}$

The practice regarding publication of notices will be guided by the prevailing procedure for legal notices in the different states. The committee on a model tax collection law of the National Municipal League recommends that, "notice shall be published once in the first and once in the last of the four calendar weeks preceding the calendar week containing the day appointed for the sale in a newspaper of general circulation in the taxing district and which has circulated generally in the taxing district for at least one year prior to the date of such publication. It shall also be posted in five conspicuous public places at least four weeks before the day ap-

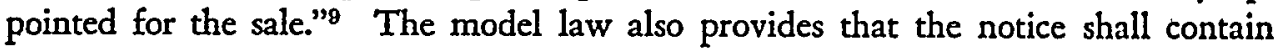
a description of the real property to be sold as it appears upon the duplicate, the owners' name if known, and the amount due with penalties and costs. Finally, it is provided that the collector shall mail a prepaid copy of the notice to the owner, if his name and address are known.

Inaccurate records of ownership, lost owners, and incorrect land description often make it difficult to give proper notice as well as to enforce the succeeding steps in the tax collection procedure. These difficulties can be somewhat alleviated by periodically checking the records of land transfers and by noting the sources of remittances for taxes. Improper notice of the tax sale has been given in some places because officials, as an economy measure, dispensed with the publication of the delinquent lists. Making the enforcement of the various provisions mandatory, as previously suggested, should remedy this situation.

The governmental unit conducting the sale is usually responsible in the first instance for the payment of costs of publishing the notices of sale, and if the property is redeemed, these costs are included among other redemption charges. Under the Jones-Munger Law enacted in Missouri in I933 specific provision was made for the payment of the cost of printing notices by the purchaser. ${ }^{10}$ The purpose of this provision was obviously to relieve the county of these costs. Some of the effects of the law, however, were probably not anticipated. The shortage of tax buyers and the fear that a sufficient number of tracts would not be purchased to cover costs of advertising have caused a few newspapers to refuse to publish the lists.

-Fourth Report of the New York State Commission for the Revision of the Tax Laws, x7 N. Y. State LEers. Doc. No. 56 (1934), p. 52.

- Report of the Committee, supra note 4, 2t 299.

${ }^{20}$ Mo. Laws 1933, P. 425. 


\section{The Tax Saze}

Although it seems desirable that the order for a tax sale should issue from a court, in approximately two-thirds of the states it is purely an administrative act, authorized by statute. Illinois is an example of a state in which the order for the sale has judicial authority. Upon petition of the collector at a specified time in this state the court renders a blanket judgment and issues a general order for the sale.

The most common type of tax sale procedure is that in which certificates are sold and redemption is permitted for a certain period, after which a tax deed is issued.11 A second type of procedure in operation in a few states provides for the automatic purchase of all delinquent tax liens by the state or county. The laws of California, Idaho, and Utah illustrate this second type. The state automatically purchases the delinquent tax liens in California and Idaho, and the county is the purchaser by operation of the law in Utah. These laws provide for the liquidation of the liens after a fixed period.

The procedure in Ohio is illustrative of a third type of procedure which obtains in a few states. No provision is made for the sale of certificates, but the tax lien is foreclosed by legal process and the property is sold three years and eight months after delinquency. Missouri had a similar procedure before the adoption of the Jones-Munger Law in 1933.

Included in a fourth group are a limited number of states in which tax certificates are sold and a fixed period of redemption allowed which is followed by a proceeding to enforce the lien by foreclosure in a manner similar to a mortgage foreclosure. Various modifications of this general plan are found in North Carolina, Nevada, New Jersey, and Nebraska. In Oregon and Washington the sale is private, but if no sale has been effected within a certain period from the delinquent date, a certificate is issued to the county and foreclosure proceedings are begun immediately.

The tax collection laws of Illinois ${ }^{12}$ are illustrative of the first and most common type of procedure. The principal provisions of this procedure include $(I)$ the sale of tax certificates to private individuals, (2) forfeiture to the state in the absence of private bidders, (3) right of redemption for two years after date of sale, and (4) issuance of a tax deed without foreclosure at the expiration of the redemption period.

The tax sale is held in Illinois, upon the order of a court, approximately four months after the delinquent date of the first instalment. The penalty from the date of delinquency to sale date is one per cent a month. The successful bidder at the sale is the person who is willing to accept the lowest rate of interest on the tax certificate, the legal maximum being twelve per cent. The penalty for the first six months is the rate bid at the sale, twice the rate for the second six months, three times the rate for the third six months, and four times rate for the last six months. A deed

"See Chattere, The Exforceycext of Real Estate Tax Luens (Municipal Administration Service, 1928) 9-10.

${ }^{11}$ See IrI. REv. Stat. (Smith-Hurd, I935) c. 120, 55 170-215. 
issues if the property is not redeemed with the two-year redemption period. In the absence of a bid sufficient to cover the taxes, the property reverts to the state and a flat-rate annual penalty of ten per cent is imposed. The Illinois law also provides for the foreclosure and sale of forfeited lands, but this law is inoperative in most counties.

A majority of the states employ a procedure similar to that of Illinois, but there is a noticeable lack of uniformity in the details. Twenty-one states provide that the real estate shall be sold to the highest bidder, although most of them require that only enough of the property be sold to cover the amount to be collected. In ten other states the successful bidder is the buyer offering to pay the amount due for the least quantity of land. The successful bidder in eight states is the person who offers to pay the amount due at the lowest rate of interest or penalty, the maximum rate usually being fixed by law and ranging from eight to eighteen per cent. In six states the property is sold to the buyer who offers the amount due.

It is usually stipulated that no amount less than taxes plus costs can be accepted; but some states make provision for selling the property for less than taxes and costs when the amount exceeds the value of the property. In Missouri, if the property does not sell for taxes and costs for two successive years, it is sold the third year for whatever it will bring. According to local officials, some taxpayers in this state, recognizing the shortage of tax buyers in recent years, have deliberately permitted their property to become delinquent, knowing that they could purchase it for a small sum the third year. After being restored to good standing, the property is then permitted to become delinquent again.

The purchaser at a tax sale is usually given some kind of legal instrument which evidences his interest in the property. This may be called a tax certificate, a certificate of purchase, or a certificate of sale. In some cases it is called a tax deed, but it does not, of course, convey valid title to the property.

The proceed's of tax sales are usually distributed among the tax-levying jurisdictions according to their proportionate interests. Each unit does not bear its proportionate share of tax delinquency, however, in Idaho, New Jersey, New York, New Hampshire, Washington, Oregon, Wyoming, and Wisconsin.

\section{Reversion of Forfeited Property ${ }^{13}$}

Within the last five years many tax sales have been devoid of purchasers for the tax liens. With a few exceptions the tax sale laws of the states provide for such a contingency. Twenty-seven states provide for bidding in the property if the statutory price is not offered by a private buyer. In nine states authority is given the governmental unit to bid in the property, but the action is not compulsory. In three states, Illinois, Ohio, and North Dakota, forfeited property automatically reverts to the government. In three other states, Indiana, Missouri, and Rhode Island, the land is never acquired by the government.

In connection with this topic, see Wager, Utilization of Reverted Tax Delinquent Land in Rural Areas, infra, p. 453. 
Eligibility for the benefits of the Fulmer Act after June $3^{0}$, 1942 is contingent upon the adoption of appropriate tax delinquency laws prior to that date. ${ }^{14}$ Included among the measures required is provision by law for the reversion of title of tax delinquent lands to the state or a political unit thereof.

Property reverts to the state if not sold in fourteen states and to the county or other local governmental unit in the remaining states except in a few instances where the sale may be continued or postponed. Whether forfeited property should revert to the state or the county is a controversial question. From a legal standpoint it should revert to the state since property rights are created by the state. The state would also seem to possess an advantage in the administration of forfeited property. Coöperative arrangements with the federal government could thereby be better facilitated; and lands adapted to county or municipal administration might be conveyed to them. In any event, the unit to which forfeited lands revert should probably make some settlement with the other jurisdictions for the loss of the tax base.

Tax receivership laws designed to alleviate the loss of revenue from forfeited property have been enacted in Illinois, Minnesota, New Jersey, and Ohio. ${ }^{15}$ The lack of adequate facilities for the administration of the extensive holdings of forfeited property is no doubt one of the most serious weaknesses of existing tax collection laws.

REDEMPTION

The term "redemption," according to Hunter, refers to the right of the original owner to demand a reconveyance. ${ }^{16}$ Except in a few states like Ohio in which there is a long period of delinquency and redemption is not permitted after the sale, sales of real estate are made subject to redemption during a specified period. The privilege of redemption is usually extended to the owner, the owner of a part interest, or to any person with a legal interest such as a mortgagee.

The redemption period is one year in thirteen states; two years in nineteen states; three years in eleven states; and four years in one state. The usual provision is that the person redeeming the property must pay the price paid at the tax sale, plus an additional flat-rate penalty and/or interest from the day of sale. The penalties when the tax lien is held by the government sometimes differ from those which apply when the certificate is held by an individual. The redemption period, generally with reduced interest or penalties, was extended by twelve states in 1935.17

As a general principle, the length of the period of redemption should represent a fair compromise between the rights of the owner and the interests of government. The model tax law of the National Municipal League suggests a period of one year from the date of sale, or at any time thereafter until the right to redeem has been foreclosed. ${ }^{18}$ This assumes, of course, that the sale is held soon after the delinquent date.

${ }^{14}$ The Fulmer Act, 49 SrAT. 963 (1935), i6 U. S. C. A. $\$ 567$ (a), provides federal financial aid to states for the acquisition of forest land.

${ }^{15}$ For a discussion of this legislation, see De Long and O'Brien, Tax Receiverships, supra, p. 382.

Lunter, supra note $\mathrm{I}$, at i7.

${ }^{17}$ Manning, supra note I, at 23. 


\section{Validity of Tax Titzes}

"A tax deed," according to Chatters, "issued at the expiration of the statutory redemption period of a tax certificate, with no judicial process involved, is a poor instrument in the eyes of land title examiners and courts of law."10 This statement is confirmed by answers to a questionnaire sent the state tax administrative agencies. ${ }^{20}$ According to these reports, tax titles are weak or questionable evidences of ownership in nineteen states; in eight states a tax deed conveys a merchantable title. A tax deed issues in Illinois at the end of two years, but it requires nine years to mature the deed.

By statutory provision tax deeds have been made prima facie evidence of the facts stated therein in nearly every state. This shifts the burden of the proof to the person attacking the validity of the sale. Statutes making tax deeds conclusive evidence of the facts stated therein, however, have been declared unconstitutional in many cases.

In order to secure tax titles from attack, it is desirable, therefore, that tax liens be enforced by a proceeding similar to that used in foreclosing mortgages. This affords the owner a day in court, giving him an opportunity to present his defenses.

The cost of foreclosure might be used as an argumeht against its adoption. A study made by C. H. Hammar showed that during the period 1927 to 1932 in Missouri the number of transfers in which costs exceeded considerations was greater than those in which considerations exceeded costs. ${ }^{21}$ It would seem that the cost of foreclosure might be markedly reduced by requiring the public prosecutor to handle them in blanket form for a nominal fee. A combination of causes of action is authorized in Nebraska, Washington, Oregon, and Texas. To the extent that foreclosure produces a valid title, it might facilitate public purchase of submarginal lands in places where such purchase is handicapped by title difficulties.

Another objection to a foreclosure proceeding is the difficulty of serving process on unknown and/or non-resident owners and minors. The model tax law suggests a solution of this problem by a procedure in rem as an alternative to foreclosure by proceedings in personam. ${ }^{22}$ Under this plan, it would be possible to serve a sum. moss by publication. In lieu of naming the defendants, it makes it possible to describe them in the summons and other papers in the action. ${ }^{29}$

\section{Efficacy of TAX-Sale Machinery}

The shortage of buyers for the tax liens in many states in recent years raises a question as to the advisability of selling certificates to private buyers during the running of the redemption period. The serious breakdown of the tax-sale machinery

\footnotetext{
1s Report of the Commithe, supra note 4, at 301.

${ }^{20}$ Cenutreas, op. cit. supta note $\mathrm{I} \pi$, at 13.

${ }^{\infty}$ From incomplete replies to 2 questionnaire sent to state tax administrative agencies by the Resettlement Administration.

mammar, Land Tax Delinquency in Missouri (Agr. Exper. Station, Univ. of Missouri, 1935) 34.

${ }^{2}$ Report of the Committee, supra note 4 , at 303 .

- See Brandis, Tax Sales and Foreclosures under the Model Tax Collection Law, infra, p. 106.
} 
is attested by the fact that sixteen state tax administrative agencies reported that the tax sale has operated unsatisfactorily in recent years, while only nine agencies reported successful operation.

The logical argument in favor of a sale of tax liens to private buyers is that it places the government in immediate possession of funds, the receipt of which would otherwise be delayed. Alyea observes that the burden to the state of forfeited lands is a function of two variables: "First, the absolute value of the taxes so invested. Second, the turnover of the investment."24 Data are not available to afford a factual basis for the purpose of comparing tax collections in states with and without a sale of tax liens. It is a fact, however, that in the pre-depression era real estate tax delinquency did not constitute a very large percentage of the total tax levy in most states. Moreover, a large proportion of delinquent tracts were redeemed before sale.

While the government would suffer some loss of revenue from the current taxes if no provision had been made for sale of liens to individuals, this would be partly offset by a flow of revenue from redemption of tracts which had been delinquent in previous years. The net effect of having no tax sale to individuals, then, might be only a small decline in tax collections. If necessary, a revolving fund might be established to stabilize the flow of revenue. Eighteen state tax administrators reported that in normal times the turnover of delinquent taxes is rapid enough that back taxes collected each year would largely offset current delinquency; six indicated that it would not be sufficient.

Another argument against the sale of tax certificates to private buyers is that during a period of depression when tax delinquency is high tax buyers refrain from purchasing the liens. A majority of the certificates in most states are bought by professional tax buyers. These purchasers naturally operate to some extent with borrowed funds; they purchase tax liens for the high rate of return on the investment, and often not because they desire or expect ever to take title to the property.

To the extent that purchasers of tax certificates operate with borrowed funds, the general credit stringency has been a factor in the decline of tax sales. The purchase of tax liens has no doubt been further deterred by the fact that tax titles are weak evidences of ownership in many states. The procedure thus breaks down at the precise time when there is the greatest need for its successful operation. If tax liens are held by the government, the owners are naturally not required to deal with private persons when they wish to redeem their property. Finally, if the liens are not sold to individuals, the government rather than private persons collects the penalties.

Whether liens are sold to private buyers or not, machinery should be established to administer chronically-delinquent lands. This is desirable to control unethical promotional activities in such lands, to reduce public and private expenditures, and to convert such lands to their highest permanent uses.

"Alyea, supra note $\mathrm{I}$, 2t 34. 